\author{
JOLANTA AMBROSEWICZ-JACOBS \\ ORCID: 0000-0001-7741-9756 \\ Uniwersytet Jagielloński
}

\title{
Remembrance and education about the Holocaust and Gulag crimes at selected museums and memorial sites in the context of learning from the past and human rights education
}

\begin{abstract}
Visits to memorial sites can provide a broader understanding of what human rights are. They help you to understand how important it is to create a world with room for everyone.
\end{abstract}

FRA Study, Student, Denmark ${ }^{1}$

\section{Introduction}

This text, dealing with education in museums and at memorial sites, was inspired by the work of many inter-governmental and national institutions (both governmental and non-governmental): The Holocaust and United Nations Outreach Programme, created at the request of the United Nations General Assembly (resolution 60/7, adopted on $1^{\text {st }}$ November 2005), UNESCO, Yad Vashem, The Holocaust Martyrs' and Heroes' Remembrance Authority in Israel, the United States Holocaust Memorial Museum (USHMM), Anne Frank House in Amsterdam, the House of the Wannsee Conference and many others. Also very useful were the strategies, approaches, lists of sources, practices, and outcomes of the international community: International Holocaust Remembrance Alliance (IHRA), former Task Force for International Cooperation on Holocaust Education, Remembrance and Research

${ }^{1}$ Discover the Past for the Future: The Role of Historical Sites and Museums in Holocaust Education and Human Rights Education in the EU, Vienna 2010, https://www.eduserver.de/ onlineressource_e.html?onlineressourcen_id=44741 (access: 24.08.2018). 
(ITF), ${ }^{2}$ OSCE/ODIHR, Council of Europe (CoE),${ }^{3}$ Fundamental Rights Agency of the EU (FRA) and their effort to research, educate and commemorate the victims of the Holocaust. The International Coalition of Sites of Conscience (http://www. sitesofconscience.org/) provided information on museums of the Gulag and their effort to commemorate Soviet crimes and teach about them in connection with Human Rights Education (HRE).

The empirical studies, guidelines addressing more general aspects of education, freedom of religion or belief, educational toolkits and the Stiftung Erinnerung, Verantwortung und Zukunft Foundation (EVZ) (Remembrance, Responsibility and Future Foundation $)^{4}$ programme "Teaching Human Rights" which attempts to connect education about human rights (HRE) and history learning (HL) have also played a crucial role in collecting the vital outcomes of previous research. The programme supported 40 projects dealing with historical discrimination, with current immigration, and with the treatment of challenged people in society. Some projects emphasised the crimes of National Socialism (NS) and contemporary HR infringements in the same area or targeting the same subjects.

The Fundamental Rights Agency (FRA) and Yad Vashem have developed the "Educators' Toolkit on the Holocaust and Human Rights Education in the EU"5 as a practical guide for teachers and educators, to provide insights into the content and methodologies of HE and HRE which can be used when teaching about and from the Holocaust and HR. ${ }^{6}$ Earlier Yad Vashem, together with the OSCE/ ODIHR, developed guidelines providing suggestions for educators "Addressing Anti-Semitism: Why and How? A Guide for Educators". The Toolkit targets educators who are willing to develop teaching projects by linking HE to HRE and is based on the FRA report documenting an empirical study in 27 EU member states Discover the Past for the Future: The Role of Historical Sites and Museums in Holocaust Education and Human Rights Education in the EU (hereafter referred to

2 The Education Working Group (EWG) of the ITF (currently IHRA) developed guidelines on Holocaust education. These guidelines are available in several languages: https://www.holocaustremembrance.com/educational-materials/how-teach-about-holocaust-in-schools (access: 24.08.2018).

3 The CoE programme "Teaching remembrance of the Holocaust - education for the prevention of crimes against humanity," which has been running since 2001, included a preventive dimension, particularly significant in an approach taken into consideration in this text.

4 The rationale of the Foundation, initially founded to handle compensation payments to former forced labourers of the Third Reich, is remembrance of the victims of the National Socialist regime, a critical assessment of history and the support for human rights. An overview of 20 selected projects is included in the Foundation's leaflet "Teaching human rights. A funding programme for human rights education through history learning. Information and selected projects", 2013.

5 Educators' Toolkit on the Holocaust and Human Rights Education in the EU is launched in 2011 guide which inspires educators to develop own projects and allows educators to present their own work online.

${ }^{6}$ http://fra.europa.eu/fraWebsite/toolkit-holocaust-education/index.htm (access: 24.08.2018).

7 Addressing Antisemitism: Why and How? A Guide for Educators, https://www.yadvashem. org/yv/en/education/ceremonies/pdf/antisemitism_guidelines_english.pdf (access: 24.08.2018). 
as the FRA Main Report and Summary Report). ${ }^{8}$ The study consisted of a survey of ministries, a separate survey carried out in 22 museums, memorial sites and non-governmental institutions, focus group interviews with 118 teachers and students in 9 EU member countries (The United Kingdom, France, the Netherlands, Austria, Germany, the Czech Republic, Poland, Italy and Lithuania), on-site visits with participant observation in 12 locations and historical museums as well as individual interviews with guides and experts in pedagogy. Multiple methodology allowed the expectations of students to be compared with the goals of educators and guides to reveal the determinants of the impact of visits on students and to examine whether they are taken into consideration by the social agents of the museum and memorial site. The research included an analysis of the literature on teaching about the Holocaust and HRE in museums and at memorial sites. The above-mentioned Toolkit is linked to the FRA Handbook Excursion to the Past - Teaching for the Future: Handbook for Teachers ${ }^{9}$ which gives guidance to teachers on how they can approach museums to teach about the Holocaust and Human Rights (HR). ${ }^{10}$

At the International Forum on the Holocaust in January 2000, representatives of 46 countries signed a common declaration (known as the Stockholm Declaration) defining the commitments of the ITF (IHRA) members. It clearly states that "the Holocaust (Shoah) fundamentally challenged the foundations of civilisation". The heads of states agreed to strengthen the moral commitment "to ensure that future generations can understand the causes of the Holocaust and reflect upon its

8 Discover the Past for the Future..., https://www.eduserver.de/onlineressource_e.html? onlineressourcen_id=44741 and the Summary Report, http://fra.europa.eu/sites/default/files/fra uploads/1792-FRA-2011-Holocaust-Education-Summary-report_EN.pdf (access: 24.08.2018). The research commissioned by the FRA, using the triangulation method of research, gathering data from various sources, confronting answers to the same research questions obtained using a variety of research techniques, was conducted by the Swedish governmental agency Living History Forum (LHF) with a team of experts: Anna-Karin Johansson, (LHF), Wolf Kaiser (House of the Wannsee Conference, Berlin), Jolanta Ambrosewicz-Jacobs (Centre for Holocaust Studies, Jagiellonian University, Cracow), Monique Eckmann (University of Applied Sciences of Western Switzerland, Geneva), Barry van Driel (Anne Frank House, Amsterdam), Verena Haug (Diplom Pädagogin at the Johann Wolfgang Goethe University in Frankfurt am Main), Paul Salmons (Institute of Education, University of London), Birgitta Löwander (LHF), Eva Fried (LHF), Christer Mattsson (LHF), Oscar Österberg (LHF), Christina Gamstorp (LHF) and Stefan Andersson (LHF). It should be noted that the subject matter of the FRA study was only education in museums and at memorial sites, not in schools. The whole report: http://fra.europa.eu (access: 24.08.2018).

9 Excursion to the Past - Teaching for the Future: Handbook for Teachers, Vienna 2010, http://fra.europa.eu/sites/default/files/fra_uploads/1218-Handbook-teachers-holocaust-education EN.pdf (access: 24.08.2018).

10 Human Rights Education at Holocaust Memorial Sites across the European Union: An Overview of Practices, FRA 2011, http://fra.europa.eu/sites/default/files/fra_uploads/1790-FRA2011-Holocaust-education-overview-practices_EN.pdf (access: 24.08.2018) was the last publication of FRA resulting from the empirical studies in EU states and discussions during the conference organised by the FRA, European Commission and the Terezín Memorial in October 2010, presenting approaches to HE and HRE in eight selected museums and memorial sites. 
consequences". ${ }^{11}$ The IHRA Multi-National Education Research Project (referred hereafter as IHRA ERP), whose objective was to identify and analyse empirical research on HE conducted in fifteen languages, was also taken into account in this text. ${ }^{12}$

\section{Historical background}

The Holocaust provides us with an awareness that democratic institutions and values are not automatically sustained; and that the Holocaust occurred because individuals, organizations, and governments made a choice which legalised discrimination and permitted hatred and murder to occur. ${ }^{13}$

The wounds caused by the Second World War are not yet healed and this is particularly the case in relation to the "Bloodlands"14 areas occupied by both regimes alternately. Some countries suffered from aggression by both states, e.g., the secret provisions of the Molotov Ribbentrop Pact in 1939 destroyed the Polish state, marking the collective memory of generations to come. The political terror of the Soviet occupation in the Baltic States with its deportations to Central Asia had multiple consequences, including both seeing the Nazis in the Baltics as liberators from Soviet rule and complicity in the Holocaust. After the fall of communism, the process of building collective identity was based on the concept of the "Soviet genocide" with the attempt to get recognition of their own victimhood. This concept has also been essential in the processes involved in building states.

Before the fall of communism, Soviet crimes were not present in historical narratives and official public memory in many countries. All crimes were attributed to the Germans, and the invasion of Poland in 1939 by the Soviet Union was presented as having been intended to protect Polish citizens. In 1940, on Stalin's orders, more

11 In 1998 Sweden initiated a national campaign under the leadership of Prime Minister Göran Persson which was aimed at increasing knowledge about the Holocaust among young people. This crucial initiative was followed in 2000 by the Stockholm International Forum on Holocaust Education, Remembrance and Research attended by a significant number of high level representatives from 46 countries and which resulted in the signing of the Stockholm Declaration and the establishment of the Task Force for International Co-operation on Holocaust Education, Remembrance, and Research (ITF), currently IHRA. Among other commitments it committed the members to introducing and implementing education about the Holocaust, promoting remembrance and research about the Holocaust, remembering the victims, respecting the survivors, and facilitating the opening of archives.

12 An international mapping of research shares concepts and effective teaching methods between countries: International Holocaust Remembrance Alliance, Research in Teaching and Learning about the Holocaust. A Dialogue Beyond Borders, eds. M. Eckmann, D. Stevick, J. Ambrosewicz-Jacobs, Berlin 2017.

13 S. Milton, "Holocaust education in the United States and Germany", [in:] Learning from History. The Nazi Era and the Holocaust in German Education, eds. A. Brinkmann et al., Bonn 2000, pp. 14-15.

14 T. Snyder, Bloodlands: Europe Between Hitler and Stalin, New York 2010. 
than 21,000 Polish officer prisoners of war were shot in Katyn, Kharkiv and Tver by the NKVD and the police. The crime was denied and attributed to the Germans. In 1930-1940 more than 300,000 Poles were deported to Siberia or Kazakhstan. The Katyn burial site was discovered by the Germans in 1943 but remained a "German" crime and a public non-memory until the fall of communism, surviving only as a hidden memory of Soviet crimes, preserved within the families affected.

The Soviet terror did not leave many material remains which could become memorial sites. The camps of the Soviet system were built in remote areas of Siberia, swamps in Belarus and in many other locations where cold weather coupled with slave labour sufficed on their own to kill their inmates. After 1945 and the incorporation of Eastern Poland, the Baltic States and part of Bessarabia into the Soviet Union, silence was imposed over Soviet crimes in all of the countries under Soviet influence. Until the fall of the Iron Curtain, there was also silence about the Holocaust in this part of Europe, much longer than elsewhere, although the myths of resistance or neutrality were willingly endorsed in Western Europe, and in some states remained in place as late as the 1980s. There is no doubt that the aftermath of the Holocaust, the most severe proof of the consequences of the denial of rights, haunts the citizens of Europe.

The Holocaust, the mass murder of Jews, including their initial isolation, discrimination and persecution, between 1933 and 1945 marked the landscape of Europe with 20,000 camps for millions of victims. ${ }^{15}$ But not all Jews were killed in the camps. The "Holocaust by bullets" or "hidden Holocaust" is a term depicting the killing of more than 2 million Jews between 1941 and 1944 during the invasion of the Soviet Union by Nazi Germany. ${ }^{16}$

The Holocaust has affected, and continues to affect, some individuals, and groups as big as nations, up until the present day, making states, national groups and individuals uncomfortable, revealing dark pages of national histories and family memories. Six former death camps were located in occupied Poland. Barbara Kirshenblatt-Gimblett wrote "the whole country is already a Holocaust museum. Poland was the epicentre of the genocide. The Germans built all the death camps on the soil of occupied Poland". 17

The goal of the Adolf Eichmann trial in 1961, when, significantly, survivors were present as witnesses, was to provide a history lesson. The questions that were asked are still valid and relate to both the origins and the consequences of the Shoah. Contemporary museum and memorial sites at the former death and concentration

15 According to the Holocaust Encyclopedia of the USHMM, http://www.ushmm.org/wlc/en/ article.php?ModuleId=10005144 (access: 24.08.2018).

16 P. Desbois, The Holocaust by Bullets: A Priest's Journey to Uncover the Truth Behind the Murder of 1.5 Million Jews, English trans. by C. Spencer, New York 2008, p. 151.

17 B. Kirshenblatt-Gimblett, "Historical space and critical museologies: Museum of the history of Polish Jews", [in:] From Museum Critique to the Critical Museum, eds. K. Murawska-Muthesius, P. Piotrowski, Farnham 2015, p. 152. 
camps "through their topographical and material existence, which creates spatial continuity between past and present [...] highlight the impact of these [National Socialist] crimes on people's lives and seek to promote a confrontation with history". ${ }^{18}$ The Centre for Studies of the Holocaust and Religious Minorities in Oslo (HL Senteret Oslo) states as its rationale the "combining of knowledge of the past with the democratic orientation in the present". Several memorial sites related to the Second World War and the Holocaust include in their names the term "human rights," for example The Falstad Centre and Human Rights Centre in the former SS prison camp in Northern Norway or the Kazerne Dossin - Memorial, Museum and Documentation Centre on Holocaust and Human Rights in Mechelen, Belgium.

\section{Competing narratives}

In keeping silent about evil, in burying it so deep within us that no sign of it appears on the surface, we are implanting it, and it will rise up a thousand-fold in the future. When we neither punish nor reproach evildoers, we are not simply protecting their trivial old age, we are thereby ripping the foundations of justice from beneath new generations. ${ }^{19}$

Different historical narratives and collective memories linked to the construction of national identity still divide Western and Central-Eastern Europe. The framework of HRE addressing the universality and interdependence of HR: the right to life, prohibiting torture, slavery, and forced labour, guaranteeing liberty and security, no punishment without the law, non-discrimination, equality and inclusion may have the potential to overcome divisions connected with national approaches to history. They may connect young people to "negative" memory and shameful, hidden, distorted historical narratives of the past of their own countries. Every nation has its own narrative of history and narratives in education, and in every nation pride and shame (often concealed) are present in politics, contributing to tensions. ${ }^{20}$ The attitude of European societies towards the Holocaust is one of the themes still not included in many curricula. ${ }^{21}$ The history of the Holocaust in many countries still waits for contextual approaches.

18 Summary Report, FRA, p. 7, http://fra.europa.eu/sites/default/files/fra_uploads/1792-FRA2011-Holocaust-Education-Summary-report_EN.pdf (access: 24.08.2018).

19 A. Solzhenitsyn, The Gulag Archipelago 1918-1956, https:/www.goodreads.com/work/ quotes/2944012-1918-1956 (access: 24.08.2014).

20 D. Hondius, "Learning from eyewitnesses: Examining the history and future of personal encounters with Holocaust survivors and resistance fighters", [in:] As the Witnesses Fall Silent: $21^{\text {st }}$ Century Holocaust Education in Curriculum, Policy and Practice, eds. Z. Gross and D. Stevick, Cham 2015, pp. 81-94.

${ }^{21}$ Curricula, modules and projects will be used interchangeably in this chapter, depending on the context. The term "project" is a preferred one following the view of students interviewed within the FRA study: "The students also pointed out that it is important for them to be proactive 
Stalin's crimes were not genocidal, despite the enormous number of victims, and are obfuscated by the Soviet myth of the "Great Patriotic War". By the same token, the communist crimes were not generated by an attempt at genocide and cannot be equated with the Holocaust. In Sweden, most teachers teach about other genocides in the context of teaching about the Holocaust. Swedish students perceive the Soviet Union's crimes as similar to the Nazi regime's crimes. ${ }^{22}$

In Ukraine, the Holodomor, the 1932-1933 famine, is represented as the genocide of Ukrainians imposed by Stalin's policy. The Holocaust remains a challenging topic, since not only were Ukrainians not among the main victims, but they were often the perpetrators. Therefore the emphasis tends to be shifted out of Ukraine, with the emphasis on Germany and its anti-Semitism, and the death and concentration camps in occupied Poland. A victimised mythology of the Ukrainian nationalist movement created and promoted by the Ukrainian diaspora also contributes to the silencing of discussion about the Holocaust. Mention of the genocide of Jews in Ukraine is suppressed and the Ukrainians are presented as the main target of Stalin's crimes. ${ }^{23}$ The usage of the Judeo-Bolshevik myth turns Jews in the main perpetrators of the Holodomor, the central component of the new Ukrainian identity, and serves as a factor determining narratives related to the competition among victims. ${ }^{24}$ Perception of the Holodomor as genocide, met, as expected, with opposition from Russia. ${ }^{25}$

\section{Museums and memorial sites}

Each country's memorial museums were established in the process of a historical consciousness whose deepening was brought on by important historical incidents, and (they) serve as constant reminders of history's warnings that the same mistakes must not be repeated. They are the signal towers that send out the message of the pursuit of universal human rights and peace. $^{26}$

during visits. They therefore recommended an exploratory, research-based and project-oriented approach", See: Human Rights Education at Holocaust Memorial Sites..., p. 12.

22 N. Ammert, Om vad och hur må ni berätta? Undervisning om Förintelsen och andra folkmord [About What and How You Should Tell? Education about the Holocaust and Other Genocides], Stockholm 2011.

23 J. Dietsch, Making Sense of Suffering: Holocaust and Holodomor in Ukrainian Historical Culture, Lund 2006.

24 J. Dietsch, "Textbooks and the Holocaust in independent Ukraine: An uneasy past”, European Education 44, 2012, no. 3, pp. 67-94.

25 G. Kasianov, "Istoricheskaia politika v Ukraine: 2000-e gody" ["History politics in Ukraine in the 2000s"], Russkii Vopros 2012, no. 2, http://www.russkiivopros.com/index.php?pag $=$ one $\& \mathrm{id}=457 \& \mathrm{~kat}=6 \& \mathrm{csl}=58$ (access: 24.08 .2018 ).

26 R. Chin-Jung Tsao, "Museums for peace: Identity of Taiwan's peace museums and human rights parks", INTERCOM Conference Paper 2006, p. 4, http://intercom.museum/documents/26Tsao.pdf (access: 24.08.2018). 
The FRA reports assessed the inclusion of HE and HRE at memorial sites and in museums bearing in mind that each year, millions of people throughout Europe visit memorial sites at places associated with Nazi crimes, as well as museums and exhibitions on the Holocaust. A large number of these visitors (more than 50\%) are young people taking part in curriculum-based visits, study trips, educational programmes or class trips. ${ }^{27}$ But this was not the case immediately after the end of the Second World War. Museums and memorial sites were often established by former prisoners or by associations of prisoners or victims of Nazi persecution, if there were any survivors at all. Approximately 150,000 Poles were prisoners in Auschwitz. At the Auschwitz-Birkenau State Museum former Polish prisoners were the first protectors and guides. The "Jewish exhibitions" presented in the Auschwitz-Birkenau Museum and at the Majdanek Museum until 1949 were later taken down. The memorials in the former death camps Chełmno, Bełżec, Sobibór and Treblinka were only erected in 1963-1965 and were not present in the collective memory due to, among other factors, a lack of survivors and the "iron curtain" dividing Europe where, in the states controlled by the Soviet Union, the dominant theme was "antifascist" rhetoric legitimising socialist political systems and disguising the core of the Holocaust crimes.

In the case of crimes against humanity committed, not in the camps, but on the streets and in the forests, or in cases where the camps were destroyed, the monuments and new museums fulfil commemorative and educational functions. The vision of the planned Sleuk Rith Institute in Phnom Penh, the capital of Cambodia, is to combine a Museum of Memory, a Research and National Policy Development Centre, and an Academy of Genocide, Conflict and Human Rights Studies. The vision combines learning about past crimes against humanity with future oriented policies increasing understanding of HR and empathy. The aim of the Institute is "to reconcile the destructive legacy of the Khmer Rouge with Cambodia's enduring cultural heritage through a focus on the timeless values of justice, memory, and healing". 28

In so many cases, the confrontation with the past is far from being completed. The Armenian genocide remains unrecognised not only by Turkey, but by the USA as well. Slavery, colonial violence, the massacres of indigenous peoples and other historical victimisations are still under-researched subjects requiring proper examination and commemoration, also in the light of the HR context, to build meaningful education upon them.

Museums and memorial sites, significant agents of historical socialisation, are carriers of the memory of wars, genocides, slavery, totalitarian regimes, crimes against humanity, mass atrocities and memories of their victims. Non-formal historical education at memorial sites is a form of historical education based not, and

27 Discover the Past for the Future..., p. 7; Excursion to the Past..., p. 26.

28 http://www.cambodiasri.org/vision (access: 24.08.2018). 
this must be stressed, on teaching about, but rather on learning through the past. In the vital research commissioned by the FRA, published in the report Discover the Past for the Future. A Study on the Role of Historical Sites and Museums in Holocaust Education and Human Rights Education in the EU, HE is defined as education that takes

the discrimination, persecution and extermination of the Jews by the National Socialist regime as its focus, but also includes Nazi crimes against other victim groups, both for the purpose of deeper understanding and contextualization of the Holocaust and out of a desire to acknowledge and commemorate the suffering of numerous non-Jewish victims of the Nazi era. ${ }^{29}$

According to Tomasz Kranz (2014), director of the Majdanek State Museum, $\mathrm{HE}$, as opposed to pedagogy of memorial sites, is not a concise didactic concept and lacks theory and methodology. ${ }^{30}$ There are, however, numerous examples of good practice, both at museum and memorial sites and in non-formal education with a wide impact on visitors, mostly young people, which are worth replicating elsewhere. It is crucial to look at the activities of NGOs which mainly, though not exclusively, comprise the area of informal education, with the reservation that in the case of many projects related to HE and HRE the terms "formal education" and "informal education" are purely descriptive, and in practice the scopes of both categories overlap.

Today, some of the former labour, concentration and death camps are museums and memorial sites and serve as material evidence, after the fall of communism, counteracting the tendency to neutralise the Holocaust specific features. This tendency may lead to universalisation, presenting the mass murder of Jews as one of many events proving the presence of evil in human nature. While the universal aspects of the Shoah are present in people's perception and culture, it is vitally important not to overshadow who were the victims and why. The great Polish-Jewish poet Julian Tuwim wrote with great eloquence in the book "We, Polish Jews":

And there shall be in Warsaw, and in every other Polish city, some fragment of the ghetto left standing and preserved in its present form in all its horror of ruin and destruction... and every day we shall twine fresh live flowers into its iron links, so that the memory of the massacred people shall remain forever fresh in the minds of generations to come, and also as a sign of our undying sorrow for them. ${ }^{31}$

This sorrow, as we all know very well, was not expressed after the Holocaust. More urgent needs to rebuild destroyed Europe had emerged. Perhaps in so many areas, education, particularly non-formal education carried on from the need of the heart of so many educators, is a form of long delayed mourning for European Jews.

29 Discover the Past for the Future..., p. 9.

30 T. Kranz, "The pedagogy of remembrance as a form of museum education", The Person and the Challenges 4, 2014, no. 2, pp. 257-269, http://dx.doi.org/10.15633/pch.672 (access: 24.08.2018).

31 J. Tuwim, My Żydzi polscy/We, Polish Jews, ed. Ch. Shmeruk, Jerusalem 1984. 
Students visiting the museums and memorial sites have the possibility of learning about the fate of the victims of totalitarian systems, how they were forced to be deported and became slave labourers, and how the life of Jewish communities ended. Focusing on victims, the visitors could also pay attention to oppressors and their helpers to identify mechanisms leading to the transformation of ordinary people into murderers.

The relationship between HE and HRE seemed obvious to politicians and educational policy makers but the FRA research has shown that belief in the existence of a close relationship was not confirmed by the data resulting from empirical studies. The FRA study of literature revealed two separate discourses, despite strong links assumed to occur between the two fields by the ministries of education and culture of Member States of the EU. Despite a high priority attributed to HRE, only a few examples of good practices combining the two fields of education were found in practice at museums and memorial sites.

What may be surprising, according to the FRA study, is that the awareness of the importance of HR, contrary to expectations, was only listed among the major achievements of education for young visitors at a minority of sites: Dachau Concentration Camp Memorial Site, Anne Frank House, Hartheim Castle-Place of Learning and Remembrance, Mauthausen Memorial and the Imperial War Museum. Other institutions surveyed listed the history of the site and the history of NS/Holocaust/WWII as a primary educational aim. Nonetheless educational projects connecting HL and HRE are being developed by various social actors and implemented, for example, at universities. These projects incorporate visits to museums and memorial sites as a main component of the project.

The recognition of universal HR and fundamental freedoms does not guarantee that they will be exercised in societies. Including HRE in the educational offer of museums and memorial sites dealing with the history of totalitarian regimes resulting from a lack of democracy may increase our understanding that democracy is fragile, democratic values are not inherited, but rather learned, and that they require the effort of all to maintain the principles of non-discrimination and tolerance.

The FRA study revealed that, in general, HE "rarely includes direct references to the legal tools that exist to preserve human rights today". ${ }^{32}$ The museums and memorial sites are proof of evidence of a major violation of HR and the basic right to live. But a visit alone might not be sufficient to create an understanding of the concept of HR and mechanisms for their protection. The FRA study revealed that successful HE and HRE requires active participation of the students. Sociologist Florian Znaniecki in his "Sociology of Education" (1928-1930, second edition 1973) had already noticed that the content of school education is distant and isolated from social reality and postulated an increased participation of children and youth in the real life of adults. He encouraged cooperation and acting on behalf of other

32 Excursion to the Past..., p. 10. 
groups as a factor replacing intergroup antagonism. He saw students as active partners in the process of learning. This approach is valid for the preparation of students for responsibilities in the pluralist world. Raising awareness of the HR abuses evident at historical and memorial sites and understanding the mechanisms of their violation is a prerequisite for preparation for democratic citizenship. Students may study cases of violence and mass murder and focus on future preventions of ethno-religious violence.

\section{Teaching and learning at and near the former death camp. International education at the Auschwitz-Birkenau State Museum and in Oświęcim}

We not only need to know what constitutes norms and social order violations, we need to learn how to react. ${ }^{33}$

Auschwitz became a symbol of the Holocaust and several world programmes addressing HL and HRE are present on the site of the former German Nazi Concentration and Extermination Camp Auschwitz-Birkenau in Oświęcim, Poland, for example the Global Raphael Lemkin Seminar for Genocide Prevention developed by the New York-based organization Auschwitz Institute for Peace and Reconciliation (AIPR) ${ }^{34}$ for young adults, government officials with an HR background and international criminal justice, among others, from all over the world. The programme takes its name from Raphael Lemkin, a Polish-Jewish lawyer who coined the term "genocide" and contributed to the ratification of the Convention on the Prevention and Punishment of the Crime of Genocide adopted by the United Nations General Assembly on $9^{\text {th }}$ December 1948.

The AIPR serves as Technical Secretariat of the Latin American Network for Genocide and Mass Atrocity Prevention, launched in 2012, providing an exchange of best practices for public officials. The Latin American version of the Lemkin Seminar addresses the region's current realities and the strengths of the regional system in dealing with 1) systematic human rights abuses of the past;2) the rights of indigenous peoples; and 3) the rights of political groups. Seminar participants will become the instructors that will facilitate the national implementation of the curriculum in their respective countries after $2016 .{ }^{35}$

33 M. Majewska, "Do I have to grow up to human rights?" ["Czy muszę dorosnąć do praw człowieka?"], [in:] Human Rights Start from Children and Youth Rights [Prawa czlowieka zaczynaja się od praw dzieci i młodzieży], Oświęcim 2013, pp. 57-61.

$34 \mathrm{http}: / /$ www.auschwitzinstitute.org/ (access: 24.08.2018).

$35 \mathrm{http}: / /$ www.auschwitzinstitute.org/what-we-do/latin-america-program/ (access: 24.08.2018). 
Another programme is Fellowships at Auschwitz for the Study of Professional Ethics (FASPE), under the auspices of the Museum of Jewish Heritage in New York, for students in professional schools. This is designed to address contemporary ethical issues through a unique historical context. FASPE invokes the power of place - the first-hand experience of visiting Auschwitz and other historic sites - to engage Fellows in applying the lessons of history to the ethical issues they face today. ${ }^{36}$

Adult education could be developed for various groups at the memorial sites. In 2000, the Auschwitz Jewish Centre was opened in the restored Khevra Lomdey Mishnayot synagogue in Oświęcim. The mission of the centre is to commemorate the victims of the Shoah by teaching about the life and culture of the Jewish inhabitants of the town on the eve of the Second World War. The Centre is visited by groups of Polish high school students. It also organises interactive meetings for Polish, German and Jewish youth, as well as lectures, seminars and workshops for teachers, NGO activists, police officers and trainers, US army cadets, including the "Talks on Tolerance" Series.

The International Youth Meeting Centre (IYMC/MDSM) located next to the Auschwitz-Birkenau State Museum, was connected with organisations active since the 1960s, Actions Reconciliation/Service for Peace (ARSP). This institution organises academic conferences and various events, but the main focus since 1991 is on youth meetings with the rationale of learning from history for a better future.

\section{More inspiring practices}

We believe that Monte Sole, as a place of memory of extreme violence carried out against defenceless civilians, is the ideal location for peace education... The Peace School does not seek to monumentalise the memory of what happened in 1944; rather, it embodies the choice to make the memory active in the present day. ${ }^{37}$

The Monte Sole Peace School, located near the hills of Monte Sole near Bologna in Italy, commemorates the massacre of 770 people by Nazi SS troops and Italian Fascists in 1944 while suppressing partisan resistance during the Second World War. Asking difficult questions while comparing past violence in the Monte Sole hills with the choices available in our times allows us to make connections between the past and present. This occurred during the on-site "CreARTing Common Europe" peace camp for youth from different countries in the EU and from the

36 http://www.mjhnyc.org/faspe/ (access: 24.08.2018).

37 "Places of memory as a tool for education: The 'Peace in Four Voices' summer camps at Monte Sole," The Public Historian, February 2008, http://www.sitesofconscience.org/founders/ peace-school-foundation-of-monte-sole-italy/ (access: 24.08.2018). 
Balkans. Students are involved in open dialogue and attempt to identify non-violent ways of addressing conflicts. ${ }^{38}$

Projects focused on memories of a totalitarian system may lead to the discovery of a palimpsest of memories, particularly at those memorial sites which served, as did many former concentration camps, different groups of prisoners, before, during and after the Second World War. The history and memory of the DP camps is an example of former prisoners and guards living in the same barracks next to each other. For many Jewish survivors, the end of the war was not equal to gaining freedom and starting a new life, but rather it meant waiting to be admitted to many countries hesitant to accept them.

Smaller size projects can be more easily incorporated in educational systems. These include e.g., the exhibition "The Lost Island. When Schools Turned into Prisons" which led to the development of the Karajangasse Memorial, opened in 1999 in the basement of the Brigittenau Gymnasium Secondary School in Vienna. In 1938 all the Jewish students in the school were put in the so-called Israelitenklasse and the elementary school in this building was transformed into a Gestapo camp. The project, carried out by teachers and students of the Vorgartenstrasse Polytechnic School in cooperation with the Aktionsradius Augarten Local Cultural Initiative and participants from the Gymnasium, allowed the forgotten history of Vienna, the history of the school building to be examined, and for the biographies of former students expelled from the school to be collected.

\section{Selected commemoration of Soviet crimes}

Between 1929 and Stalin's death in 1953 almost 12 million people, those the government accused of being opposed to the Stalinist system, were murdered or deported to the Gulag. Commemoration of the victims of the Soviet system is rare in Russia. The words Gulag and anti-Soviet underground were taboo and absent from public discourse.

Memorial International (a confederation of over 80 national and regional organisations from 9 countries) was the main civil society organisation devoted to research and remembrance of political repression in the former Soviet Union. ${ }^{39}$ Memorial also provided legal and social support to the victims of totalitarian regimes. Since 2001 30,000 entries with 70,000 stories have been collected for the contest "Man in History. Russia in the XX Century", often about members of students' families, containing primary sources and biographical material contributing to the history of Russia.

38 After: http://www.sitesofconscience.org/founders/peace-school-foundation-of-monte-soleitaly/ (access: 24.08.2018).

39 http://www.memo.ru/ (access: 24.08.2018). 
The website Sites of Conscience informs the world that against the backdrop of the increasing crackdowns on free speech, compounded by fading memories of Stalin's rule, the Russian Sites of Conscience Network raises awareness of the history and consequences of totalitarianism to actively engage citizens in addressing threats to Russian democracy today. ${ }^{40}$

The Perm-36 Memorial Centre of the History of Political Repression, established by the Perm branch of the "Memorial" society and the local administration, opened in 1995 on the site of a labour camp. ${ }^{41}$ The Centre commemorated the suffering of the political victims of the totalitarian system in the GULAG camps. It questioned authoritarianism and supported Russian citizens struggling for democracy. ${ }^{42}$ From 2004 onwards the Museum, in collaboration with Perm State University and Perm Regional Teacher Training Institute, organised a regional competition for teachers "The Authorities and Society: Russia on the Path to Civil Society".

The Centre was closed in early 2015 after control progressively passed to the government authorities; it reopened later that year, recast to convey an uncritical and more patriotic view. An open letter sent in 2014 to the Governor of Perm was signed by the Managing Committee of the Perm Chapter of the Memorial Society and the Council of Victims of Political Repressions, and was available on the Youth Memorial website. The letter stated: "For those who were aggrieved during the repression period, who lost their family members and friends to those repressions, who suffered from the deprivation of rights, the Memorial Museum has been a memorial to those innocent victims, our parents who died in GULAG camps and prisons." ${ }^{.43}$ In late 2015 an exhibition "The National Remembrance of the GULAG" was opened in the State Museum of GULAG History in Moscow, which after the closing of the Perm-36 Museum remains the only official Gulag museum in Russia. ${ }^{44}$

The Virtual Museum of the Gulag lists 45 small local history museums, mostly in Russia and Lithuania, displaying exhibitions about the "Red Terror." One of them is the Ust'-Tsil'ma Museum, which also organises lessons for students on the topic of "Repressions in the Ust'-Tsil'ma district." Another local history museum in Anzhero-Sudzhensk in the Kemerovo Oblast presents the history of deportations, the camp, the labour army, and the history of settlers, as part of the permanent exhibition. Very often an exhibition on the topic of the Gulag has been initiated

\footnotetext{
${ }^{40}$ http://www.sitesofconscience.org/networks/russia/ (access: 24.08.2018).

41 Perm-36, was one of the most notorious three remote camps operating from 1946 to 1988.

42 After: http://www.sitesofconscience.org/founders/gulag-museum-at-perm-36-russia/ (access: 24.08 .2018$)$.

$43 \mathrm{http} / / /$ volonter59.ru/index.php?category=65\&id=767 (access: 24.08.2018).

44 After: http://www.gmig.ru/o-muzee (access: 24.08.2018).
} 
in museums by local historians, who also have organised expeditions to find the burial sites of camp prisoners and artefacts held by the local population. ${ }^{45}$

\section{Learning from the past about totalitarian systems, but not exclusively about sombre sites}

While learning about the "negative" history of state and individual violence and mass killings, "positive" actions of the courage and heroism of rescuers should be highlighted, e.g., during the Holocaust, the genocide in Rwanda and of crimes against humanity in other places, to give examples that every action matters in a moral and historical sense. Learning about totalitarian systems should not be limited to teaching/learning exclusively about sombre sites, but should also show students examples of individuals with courage as role models of those who attempted to preserve human dignity in a time of terror, and who often risked their own lives defending the rights of others. An example is the project of The International Commission for the Evaluation of the Crimes of the Nazi and Soviet Occupation Regimes in Lithuania marking in 2015 the $75^{\text {th }}$ anniversary of the transit visas issued by the Japanese Consul General Chiune Sugihara to Jews who tried to escape from Europe in the summer of 1940. The project was joined by 12 Tolerance Education Centres associated with Lithuanian middle and high schools. Educators are advised to include personal testimonies or interviews in their projects. ${ }^{46}$

\section{Teaching about collaboration or about victimhood?}

The historical facts of the murder of Jews carried out by Lithuanians in Lithuania, Ukrainians in Western Ukraine and Romanians in Romania are still denied or downplayed in those countries. In Lithuania and other Baltic countries there is a deeply rooted belief in a "double genocide" of the victims of two totalitarian Nazi and Soviet systems. Established in 2000, the Association House of Remembrance launched a history competition for Lithuanian school students "the Jews - my Grandparents' and Great Grandparents' Neighbours." Information on how many students discovered Lithuanian collaboration is unknown.

Collaboration is a very difficult topic for all, but omitting this theme in education carries the danger of creating false collective identities of the separate populations of victims and members of the resistance. The issue of collaboration is present in the teaching aid published by the Association of Estonian History Teachers in

45 After: http://www.gulagmuseum.org/search.do?objectTypeName=museum\&page=1\&lan guage $=2$ (access: 24.08 .2018$)$.

46 For more information about people who rescued Jews during the Holocaust see: http:// db.yadvashem.org/righteous/search.html?language=en (access: 24.08.2018). 
2004 for history teachers "History is not just the past/The Past is not yet history" helping students to find arguments for Estonians to choose to fight in the Soviet or the German armies.

The Museum of Exile and Resistance in Kaunas, Lithuania, created by the Lithuanian Union of Political Prisoners and Exiles, displays exhibitions exclusively dedicated to Lithuanian political prisoners in camps and in exile, to the anti-Nazi and anti-Soviet resistance and the partisan war of the late 1940s, and to the movement for the defence of the rights of the Catholics in Lithuania in the 1970s. The artefacts displayed were collected during expeditions to the sites of labour camps and special settlements in the Krasnoyarsk region and Yakutia, and from the families of partisans. The Museum is visited by schools; the students are taught the history of the resistance and of the Soviet terror, which are included in school history courses, and the Museum leads excursions to restored partisan bunkers.

The Public Commission to Preserve the Legacy of Academician Sakharov was established in 1990, followed by the Sakharov Archive and Centre in 1994. The Sakharov Centre ${ }^{47}$ carries out awareness-building and exhibition projects on the issues of xenophobia and racism, and runs a competition for school teachers on the history of political repression. Since 2011 the Centre has run the Moscow Open Human Rights School. Cooperation with the SOVA Centre for Information and Analysis allows assistance to be given to the victims of assaults motivated by hatred. The Youth Human Rights Movement cooperates with Anne Frank House, displaying the "Anne Frank - History Lesson" mobile exhibition across Russia for more than 5 years.

The Mednoe State Memorial Complex in the Tver region was founded in 1996 and in 2003 it was reorganised as a branch of the State Museum of the Political History of Russia (GMPIR, St Petersburg). In 2006 the Mednoe Memorial Complex opened an Information and Museum Centre in Tver. The Memorial Complex comprises a memorial cemetery marking the burial site of 6311 Polish soldiers and officers from the nearby camp, an Alley of Memory comprising four mass graves of about 5000 Soviet victims executed during the 1930s, as well as the graves of unnamed Soviet soldiers who died in evacuation hospitals and medical battalions, and "View," an open-air exhibition. Every year on $2^{\text {nd }}$ September a ceremony is held at the Memorial Complex on the occasion of the International Day of Remembrance for Soviet and Polish Citizens who fell victim to political repression.

Teaching compassion seems a real challenge in education but can be successfully achieved if young people can be properly engaged in the topic and are properly prepared for visits to exhibitions at memorial sites by, for example, examining the fate of individuals and survivors' testimonies. Oral history and testimonies by individuals are considered powerful means of teaching and raising the awareness of students about the trauma of the victims. The biggest impact on educators and

47 http://www.sakharov-center.ru/ (access: 24.08.2018). 
students is from meeting with survivors who are not stuck in trauma and have overcome their horrible experience, emanating peace and forgiveness.

The "History of My Family" training course encourages local youth to record their family's experiences as the victims of state repression. The students' interviews are a starting point for discussions on the following topics: "What is the "state'?" "Why do democratic societies need a state?" "What role does each individual play in a totalitarian society?" and "How can we prevent totalitarianism from taking hold again?’48

\section{Conclusion}

To conclude, it is crucial to underline differences between Western and Central-Eastern Europe in commemorating past genocides, crimes against humanity, political violence and human rights abuses; differences between commemoration of Nazi and Gulag crimes, and competition among victim narratives. The focus on Soviet crimes in the Baltic countries and focus on the Holodomor in Ukraine has led to a relativisation of the Holocaust. The Polish case differs from a relativisation of the Holocaust because at least in public discourse and education, Nazi crimes are not presented as equal to Soviet crimes, except perhaps by some extremists preoccupied with an anti-Communist rhetoric.

Nonetheless, "historical politics" was promoted by changes in the Institute of National Remembrance (IPN) in 2006, with a new leadership opposing so called "critical patriotism" and attempting to replace it by "modern patriotism", neglecting shameful facts from the past and restoring pride in the behaviour of Poles both during the war and in general. There was an attempt to downplay the suffering of Jews. Dr. Tomasz Panfil, historian, chief of the Lublin Bureau of the "national education section" of the IPN, stated in an interview that the fate of Jews in German occupied Poland was not that bad until the deportations. Panfil also called the Jewish Councils "the organs of local self-government". Not only was he not corrected by the Minister of National Education, Ms. Anna Zalewska, but on the contrary, he was decorated on October $16^{\text {th }}, 2017$ with the medal of the Commission of National Education.

A political crisis resulted from the amendments to the law on the IPN passed on January $26^{\text {th }}, 2018$ which redevelop Polish collective identity with reference to attitudes towards Jews during the Holocaust, followed by another amendment passed in June 2018, decriminalising 'defamation of the Polish nation' but leaving civil charges in such cases. A denial of involvement of individual Poles in anti-Jewish violence during the Holocaust and after the Second World War and the focus

48 After: http://www.sitesofconscience.org/founders/mednoe-memorial-complex-russia/ (access: 24.08.2018). 
on Polish suffering may lead to representation of Polish and Jewish victimhood as equal. Such equality, despite qualitative differences, bearing in mind that each suffering is incomparable and unique is not confirmed by a vast historiography of the Holocaust.

Jews were planned to be killed as an entire group, perceived as a "race", despite their nationalities, religiosity, political orientation, place of residence, level of assimilation and many other socio-demographic determinants. The laws, introduced by very educated people in Nazi Germany, i.e., lawyers, attributed who is Jewish and who is not on the basis of "blood". An attempt to kill an entire group of those defined according to attributed features and norms makes the Holocaust a paradigmatic historical event which is evidence of the ultimate violation of HR.

Monique Eckmann, asking the vital question about whether HE should be a tool for HRE, made a distinction between education about, for and with or within a framework of HR. ${ }^{49}$ Learning about HR refers to knowledge and understanding of the history of HR and their abuses. This knowledge, as students interviewed within the framework of the FRA study revealed, is not satisfactory in formal education. In the context of HE students may learn about numerous examples of violations of HR by the Third Reich (starting with the passing of the Nuremberg Laws) and other European states. Learning e.g., about denying asylum status to Jewish refugees in the past, including analysis of the Evian Conference of 38 states, organised by the US President Franklin D. Roosevelt in 1938, can be connected to the contemporary status and reality of refugees from Syria and other countries, desperately searching for a safe place to live and unwanted or rejected by so many European states.

The USHMM developed strategies online to disseminate knowledge about the victims of ISIS. Learning for HR incorporates, apart from information, also cognitive and behavioural skills and competences to defend them and components oriented towards interventions. Cognitive skills include critical thinking, understanding of the concepts of HR, identifying causes of HR violations, ability to describe the historical process from the HR perspective, self-respect, and self-control. Behavioural skills include social networking, problem solving, applying strategies to oppose discrimination, communication abilities, and joining campaigns for victims of HR deprivations. Such learning occurs more frequently in informal education. In the context of HE, it would require an imagination about past state terror and the potential for action against it. It could be discussed during cooperative learning activities providing opportunities to act responsibly and to be just and caring for others. Learning within a framework of human rights includes experiential learning and the possibility of bringing their family's or witness' experience of discrimination.

49 M. Eckmann, "Exploring the relevance of Holocaust education for human rights education prospects", Quarterly Review of Comparative Education 40, 2010, no. 1, pp. 7-16. 
Globalisation and unification processes are accompanied by an emergence of national and ethnocultural groups with their urge for a separate identity and collective memory of the past. Distinct national identities bring a rise in xenophobia and racism, the marginalisation of minorities, exclusion of immigrants, of refugees and of asylum seekers. The approach taken in this chapter addressing HE and HRE at museums and memorial sites states, indeed emphasises, after Gundara, ${ }^{50}$ that racism and xenophobia can only be countered if agreement is reached between minorities and governments, an agreement to create an inclusive society - a society within which education must play an important role in ensuring equity at all levels. Holocaust Education (HE), in this understanding of the role of education in general, plays a special role. A call for HR protection in political speeches, however, should not obscure the fact that there are differences between the aims of HE and HRE, despite the fact that many educators take the Holocaust as a starting point for tolerance or HRE. ${ }^{51}$

Since the role of education in post-modernity is to prepare young people to understand and manage how to live in our interdependent world, learning about the difficult, often dramatic and sometimes wrong choices of our ancestors in the past may facilitate the recognition of diversity. Thus, HE can lead to a comprehension of the danger of exclusive identities being promoted by radical politicians and movements.

\section{Bibliography}

Addressing Antisemitism: Why and How? A Guide for Educators. https://www.yadvashem.org/yv/ en/education/ceremonies/pdf/antisemitism_guidelines_english.pdf.

Ammert, N. 2011. Om vad och hur må ni berätta? Undervisning om Förintelsen och andra folkmord [About What and How You Should Tell? Education about the Holocaust and Other Genocides]. Stockholm: Forum för levande historia.

Chin-Jung Tsao, R. 2006. "Museums for peace: Identity of Taiwan's peace museums and human rights parks". INTERCOM Conference Paper. http://www.intercom.museum/documents/2-6tsao.pdf.

Desbois, P. 2008. The Holocaust by Bullets: A Priest's Journey to Uncover the Truth Behind the Murder of 1.5 Million Jews, English trans. by C. Spencer. New York: Palgrave Macmillan.

Dietsch, J. 2006. Making Sense of Suffering: Holocaust and Holodomor in Ukrainian Historical Culture. Lund: Department of History, Lund University.

Dietsch, J. 2012. "Textbooks and the Holocaust in independent Ukraine: An uneasy past". European Education 44, no. 3 .

Discover the Past for the Future: The Role of Historical Sites and Museums in Holocaust Education and Human Rights Education in the EU. 2010. Vienna. http://fra.europa.eu/sites/default/ files/fra_uploads/1791-FRA-2011-Holocaust-Education-Main-report_EN.pdf; the Summary

50 J.S. Gundara, Interculturalism, Education and Inclusion, London 2000.

51 Education on the Holocaust and on Anti-Semitism: An Overview and Analysis of Educational Approaches, OSCE Office for Democratic Institutions and Human Rights (ODIHR), Warsaw 2006, p. 15. 
Report. http://fra.europa.eu/sites/default/files/fra_uploads/1792-FRA-2011-Holocaust-Education-Summary-report_EN.pdf.

Eckmann, M. 2010. "Exploring the relevance of Holocaust education for human rights education prospects". Quarterly Review of Comparative Education 40, no. 1.

Education on the Holocaust and on Anti-Semitism: An Overview and Analysis of Educational Approaches. 2006. Warsaw: OSCE Office for Democratic Institutions and Human Rights (ODIHR).

Educators' Toolkit on the Holocaust and Human Rights Education in the EU. http://194.30.15.238/ fraWebsite/toolkit-holocaust-education/index.htm.

Excursion to the Past - Teaching for the Future: Handbook for Teachers. 2010. Vienna. http:// fra.europa.eu/sites/default/files/fra_uploads/1218-Handbook-teachers-holocaust-education EN.pdf.

Gundara, J.S. 2000. Interculturalism, Education and Inclusion. London: Thousand Oaks - P. Chapman.

Holocaust Encyclopedia of the USHMM. http://www.ushmm.org/wlc/en/article.php?ModuleId= 10005144.

Hondius, D. 2015. "Learning from eyewitnesses: Examining the history and future of personal encounters with Holocaust survivors and resistance fighters". In: As the Witnesses Fall Silent: $21^{\text {st }}$ Century Holocaust Education in Curriculum, Policy and Practice, eds. Z. Gross, D. Stevick. Cham: Springer International Publishing.

How to Teach about Holocaust in Schools. https://www.holocaustremembrance.com/educationalmaterials/how-teach-about-holocaust-in-schools.

Human Rights Education at Holocaust Memorial Sites across the European Union: An Overview of Practices. 2011. FRA. http://fra.europa.eu/sites/default/files/fra_uploads/1790-FRA-2011Holocaust-education-overview-practices_EN.pdf.

International Holocaust Remembrance Alliance. 2017. Research in Teaching and Learning about the Holocaust. A Dialogue Beyond Borders, eds. M. Eckmann, D. Stevick, J. Ambrosewicz-Jacobs. Berlin: Metropol and IHRA.

Kasianov, G. 2012. "Istoricheskaia politika v Ukraine: 2000-e gody" ["History politics in Ukraine in the 2000"']. Russkii Vopros, no. 2. http://www.russkiivopros.com/index.php?pag=one\&id= $457 \& \mathrm{~kat}=6 \& \mathrm{csl}=58$.

Kirshenblatt-Gimblett, B. 2015. "Historical space and critical museologies: Museum of the history of Polish Jews". In: From Museum Critique to the Critical Museum, eds. K. Murawska-Muthesius, P. Piotrowski. Farnham: Ashgate.

Kranz, T. 2014. "The pedagogy of remembrance as a form of museum education". The Person and the Challenges 4, no. 2. http://dx.doi.org/10.15633/pch.672.

Majewska, M. 2013. "Do I have to grow up to human rights?" ["Czy muszę dorosnąć do praw człowieka?"]. In: Human Rights Start from Children and Youth Rights [Prawa człowieka zaczynaja się od praw dzieci i młodzieży]. Oświęcim: MDSM.

Milton, S. 2000. "Holocaust education in the United States and Germany". In: Learning from History. The Nazi Era and the Holocaust in German Education, eds. A. Brinkmann et al. Bonn: ARCult-Media.

"Places of memory as a tool for education: The 'Peace in Four Voices' summer camps at Monte Sole”. 2008. The Public Historian, February. http://www.sitesofconscience.org/founders/ peace-school-foundation-of-monte-sole-italy.

Snyder, T. 2010. Bloodlands: Europe Between Hitler and Stalin. New York: Basic Books.

Solzhenitsyn, A. The Gulag Archipelago 1918-1956. https://www.goodreads.com/work/quotes/ 2944012-1918-1956.

Tuwim, J. 1984. My Żydzi polscy/We, Polish Jews, ed. Ch. Shmeruk. Jerusalem: Magnes Press. 


\section{Internet sources}

http://db.yadvashem.org/righteous/search.html?language=en.

http://volonter59.ru/index.php?category $=65 \& \mathrm{id}=767$.

http://www.auschwitzinstitute.org/.

http://www.auschwitzinstitute.org/what-we-do/latin-america-program/.

http://www.cambodiasri.org/vision.

http://www.gmig.ru/o-muzee.

http://www.gulagmuseum.org/search.do?objectTypeName=museum\&page=1\&language= 2 .

http://www.memo.ru/.

http://www.mjhnyc.org/faspe/.

http://www.sakharov-center.ru/.

http://www.sitesofconscience.org/founders/gulag-museum-at-perm-36-russia/.

$\mathrm{http}: / /$ www.sitesofconscience.org/founders/mednoe-memorial-complex-russia/.

http://www.sitesofconscience.org/founders/peace-school-foundation-of-monte-soleitaly/.

http://www.sitesofconscience.org/networks/russia/.

\section{REMEMBRANCE AND EDUCATION ABOUT THE HOLOCAUST AND GULAG CRIMES IN SELECTED MUSEUMS AND MEMORIAL SITES IN THE CONTEXT OF LEARNING FROM THE PAST AND HUMAN RIGHTS EDUCATION}

\section{Summary}

Different historical narratives and collective memories linked to the constructions of national identity still divide Western and Central-Eastern Europe. The framework of Human Rights Education addressing universality and interdependence of Human Rights may have a potential to overcome divisions connected with national approaches to history. They may connect young people to "negative" memory and shameful, hidden, distorted historical narratives of the past of their own countries. The attitude of European societies towards the Holocaust is one of the themes still not included in many curricula. The history of the Holocaust and Soviet crimes in many countries still waits for contextual approaches. Museums and memorial sites in this context are carriers of memory of wars, genocides, slavery, totalitarian regimes, crimes against humanity, mass atrocities and memories of their victims. They are also significant agents of historical socialisation. History education at memorial sites is a form of historical education based not on teaching about but rather on learning through the past. The text deals with empirical studies focused on education at museums and memorial sites and will explore issues related to education about the Holocaust and Gulag in selected case studies.

Keywords: Holocaust, Gulag, collective memory, education about human rights, museums, memorial sites.

Jolanta Ambrosewicz-Jacobs

jolanta.ambrosewicz-jacobs@uj.edu.pl 
Studia nad Autorytaryzmem i Totalitaryzmem 40, nr 3, 2018 (C) for this edition by CNS 